УДК 642.011 .15

(C) 3.С. Сірко, к.т.н.

Національний університет біоресурсів і природокористування України

В.А. Коренда

Український державний науково-дослідний інститут «Ресурс»

\title{
СПОСІБ ВИГОТОВЛЕННЯ ВОГНЕЗАХИСНОЇ ФАНЕРИ
}

Сучасне будівництво промислових та громадянських об'єктів, вагонів (залізничні вагони, вагони метро) вимагають застосування деревини та інших матеріалів на їі основі підвищених експлуатаційних характеристик, до яких в першу чергу відноситься вогнестійкість та підвищений термін служби. Одним iз поширених конструкиійних матеріалів на основі деревини $\epsilon$ фанера - плитний матеріал з підвищеними фізико- механічними та експлуатаційними показниками, який застосовують в будівниитві, машино- та транспортобудуванні. суднобудуванні, вагонобудуванні, у виробництві меблів та інших виробів широкого вжитку. 


\section{ФАНЕРА, ПРОСОЧУВАННЯ, АНТИПІРЕНИ, ФІЗИКО- МЕХАНІЧНІ ВЛАСТИВОСТІ, ВОГНЕСТІЙКІСТЬ}

Постановка проблеми. За даними кон'юнктури світового ринку [1] виробництво фанери на всіх континентах невпинно зростає, в тому числі і в Україні. В першій половині 2017 року українськими підприємствами було виготовлено 0,8 млн. м $^{3}$ клеєної фанери [2].

Незважаючи на значні переваги перед іншими конструкційними клеєними матеріалами, фанера має, як і всі матеріали на основі деревини один суттєвий недолік - вона $€$ горючим легкозаймистим матеріалом і продукти горіння містять токсичні речовини. Тому створення технології виготовлення вогнезахиіценої фанери $є$ актуальною у сфері безпеки життєдіяльності та пожежної безпеки. До недавніх пір вогнезахищена фанера в Україні не виготовлялась. Натомість важкогорюча фанера виготовляється в багатьох країнах світу за технологією просочення лущеного шпону i подальшим його склеюванням у фанерні плити. Зазначена технологія складна, дорога та передбачає використання шкідливих речовин (фенольні смоли, фтористий натрій, сполуки аміаку).

Аналіз останніх досліджень і публікацій. Найбільш перевіреною й ефективною мірою захисту деревини та деревних матеріалів від горіння $\epsilon$ глибоке просочення під тиском 3 поглинанням солей 75-100 кг/ $\mathrm{m}^{3}$ методами гаряче-холодних ванн або у автоклавах [3].

Для надійного захисту деревина просочується під тиском 3 використанням способу повного поглинання [4]. Вважається, що для фанери також найбільш економічним й технологічним є спосіб глибокого просочення під вакуумом та тиском [5. 6].

За даними російських вчених, на сьогодні просоченням під тиском вже захищають антипіренами, крім будівельних конструкцій, також фанеру та столярні плити. Але недоліком цього способу є значне набрякання, усушка й розтріскування [7]. Від цього звільнюються спеціальними режимами сушіння й використання неводних неполярних рідин, що швидко випаровуються. У США виготовляють вогнезахищену фанеру просоченням шпону хімічними розчинами 3 подальшим склеюванням [8]. Більш поширене просочення готової фанери після склеювання, а потім її сушіння. У цьому випадку фанера повинна бути склеєна водотривкими зв'язками. Інші роботи також свідчать про те, що за кордоном практикують просочення готової водостійкої фанери. Але клейові з'єднання можуть заважати 
проникненню захисного розчину.

За деякими даними, для виготовлення вогнезахищеної фанери шпон краще просочувати до склеювання [9]. Концентрація водних розчинів антипірену, що складається з фосфату та сульфату амонію, становить 10-20\%. Перед просочуванням шпон висушують, дозволяється його попередньо пропарювати для покращення просочувальних властивостей.

У Росії амонійні сполуки застосовуються у вигляді 10\%них або концентрованих розчинів для просочення фанери або шпона [9]. Просочений шпон добре склеюється бакелітовою плівкою, але його не можна склеювати луговими клеями. Така фанера може використовуватися лише у сухих приміщеннях, бо у вологих швидко втрачає вогнезахисті властивості.

Є спосіб просочення шпону у холодній ванні при $20-25^{\circ} \mathrm{C}$ на протязі 2-3 годин у водному розчині фосфорної кислоти $(0,5$ $3,0 \%)$ та сірчанокислого аніліну $(0,1-1,0 \%)$ [10].

Встановлено, що з трьох способів виготовлення захищеної фанери - добавка речовин у клей, обробка готової фанери та просочення шпону - останній має перевагу [11]. Захисна речовина значно зменшує міцність склеювання, якщо іiі додавати у в'яжуче.

ЦНДІ пожежної безпеки та ЦНДІ фанери (Росія) була проведена робота 3 виготовлення вогнестійкої фанери 3 просоченого пшону. Шпон товщиною 1 мм просочували способом гаряче-холодної ванни при режимах: 6 год у холодній ванні, бгод у гарячій ванні при температурі $75^{\circ} \mathrm{C}$ з поглиненням розчину $37 \%$. У склад розчину входили амонійні солі та (3-5\%) фторида натрію. Просочений шпон склеювали бакелітовою смолою СБС-1. У порівнянні 3 контрольними зразками міцність склеювання була дещо нижчою.

В інституті хімії деревини (Латвія) проводилися дослідження [12] 3 комплексної захисної обробки клеєфанерних панелей біовогнезахисним препаратом "Модифікація МБ-1". що містить у собі (\%): буру - 1,6; борну кислоту - 3,0; сульфат міді 1,6 ; сульфат амонію - 22,0; воду - 65,8. Фанерні панелі просочували концентрованим 28\%-ним розчином при температурі (35-40) ${ }^{\circ} \mathrm{C}$ на протязі 40хв. Кількість поглиненого препарату становила 6\% від маси, утримання - $115 \kappa / \mathrm{m}^{3}$. При дослідженні за методом вогневої труби втрата маси зразків становить 5\%, самостійне горіння не перевищує 1-2сек. Тління немає (втрата маси контрольних зразків $79 \%$ ).

Вогнезахищену фанеру високої якості виготовлюють введенням вогнезахисних сполук у березовий шпон товщиною 1,0 
мм просоченням у автоклавах чи у відкритих ваннах до заданого поглинання. Для покращення введення розчинів Інколи по середині дисковою пилою робили надрізи під кутом на 20-25\% товщини середнього шпону [6].

Вогнестійку фанеру можна отримати, наносячи антипірен на шпон за допомогою вальців [13] на кожен лист шпону або на частково сформовану фанеру. Як антипірен використовували фосфорні, хлорні та азотні сполуки гуанідину (40-45) кг 3 утриманням $150-180 \mathrm{r} / \mathrm{M}^{2}$. На висушену при $80^{\circ} \mathrm{C}$ поверхню наносять вальцями клей, що містить у собі 40\% антипірену, 3 утриманням $400 \Gamma / \mathrm{M}^{2}$. Пресують фанеру при $120^{\circ} \mathrm{C}$ тиску 8-10

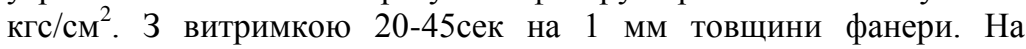
отриману фанеру знову наносять шар вогнезахисної речовини й знов підсушують.

У США запатентовано спосіб просочення деревини для збільшення вогнестійкості без підвищення гігроскопічності складом, головним компонентом якого $є$ водні розчини частково зреагувавших монометілдіціандіаміду, меламіну та фосфорної кислоти при певних молярних співвідношеннях 3 поглиненням (6$30 \%)$. Сушіння ведуть при (60-110) ${ }^{\circ} \mathrm{C}[14]$.

Процес горіння деревини та заходи, направлені на його заглушення можна зобразити схемою на рис.1.

Мета дослідження - створити вогнезахисну фанеру вітчизняного виробництва.

Результати дослідження. Виходячи із аналізу методів вогнезахисту деревини та світової практики виготовлення вогнезахищеної фанери нами розроблена технологія вогнезахисту готової клеєної фанери за регламентом вакуумного просочення в розчинах антипіренних композицій. Суть технології полягає в наступному. Повноформатна клеєна фанера або деталі із неї просочують розчином антипіренної композиції (ДСЛ-1, ДСА-2) при концентрації 30\% (питома вага не менше 1,17). температура розчину $\quad 40-50{ }^{\circ} \mathrm{C}$ в автоклав ній вакуумній установці при вакуумі 50 кПа на протязі 20-40 хвилин в залежності від товщини та формату фанери. Після просочення та видалення залишкового розчину фанера висушується за розробленими режимами. Зразки просоченої фанери випробовувались на визначення ступеню вогнезахищеності. 


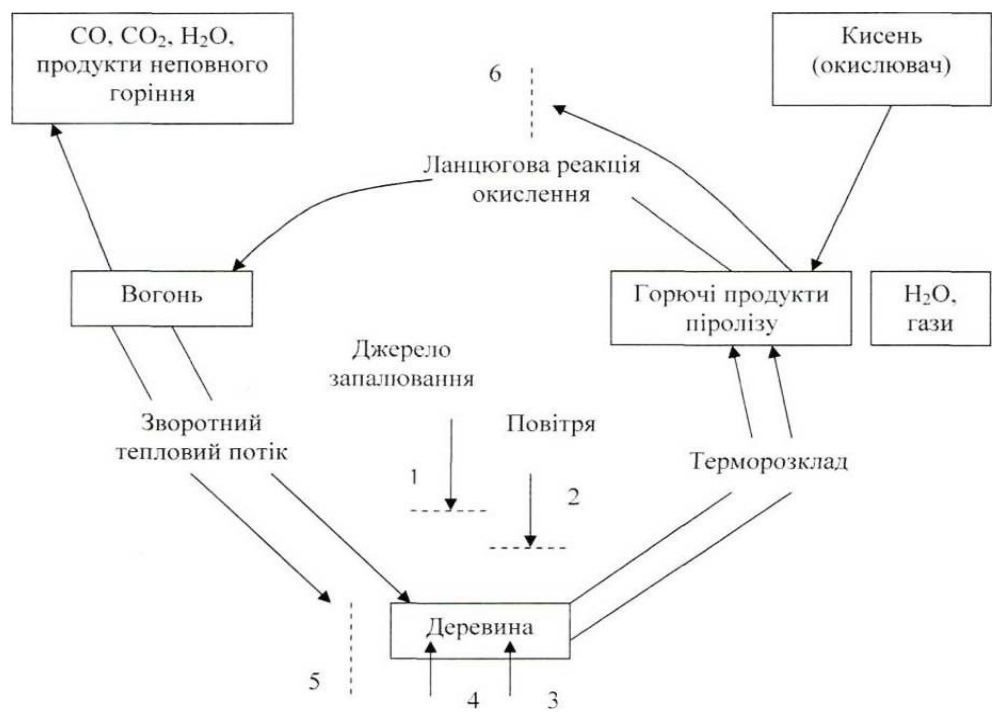

Рис. 1 - Процес горіння деревини та заходи, направлені на його заглушення

Суть методу експериментального визначення групи важкогорючих та горючих твердих речовин і матеріалів згідно 3 ГОСТ 12.1.044-1989 полягає у впливі на зразок, розташований в керамічній трубі установки ОТМ. полум'я пальника 3 заданими параметрами (температура газоподібних продуктів горіння на виході $з$ керамічної труби становить $200 \pm 5^{\circ} \mathrm{C}$ ) [15]. Під час проведення експериментальних досліджень фіксується максимальний приріст температури газоподібних продуктів горіння $\Delta \mathrm{t}$ та втрата маси зразка $\Delta \mathrm{m}$. За результатами випробувань матеріали класифікуються як:

- важкогорючі $-\Delta \mathrm{t}<60^{\circ} \mathrm{C}$ та $\Delta \mathrm{m}<60 \%$ :

$$
\text { - горючі } \quad \text { - At } \geq 60{ }^{\circ} \mathrm{C} \text { чи } \mathrm{Am} \geq 60 \% \text {. }
$$

Горючі матеріали поділяються залежно від часу т досягнення максимальної температури газоподібних продуктів горіння на:

- важкозаймисті $-\mathrm{T}>240 \mathrm{c}$

- середньої займистості $\quad-30 \leq \mathrm{T} \leq 240$;

- легкозаймисті -т $<30 \mathrm{c}$.

Результати досліджень 3 визначенням втрати маси зразків $\Delta \mathrm{m}$ та приросту максимальної температури газоподібних продуктів горіння $\Delta \mathrm{t}$ вогнезахищеної фанери сумішшю ДСА-2 наведено в 
таблиці 1.

Як засвідчують результати досліджень (таблиця 1), усі зразки фанери можна характеризувати як важкогорючі. До того ж із збільшенням товщини фанери важкогорючі властивості покращуються. Додаткове оброблення зразків кремнійорганічним гідрофобізатором «Сілол» деякою мірою зменшує ефективність вогнезахисту. але зразки відносяться до групи важкогорючих матеріалів.

Таблиця 1 - Результати досліджень з визначенням втрати маси зразків $\Delta \mathrm{m}$ та приросту максимальної температури газоподібних продуктів горіння $\Delta$ t вогнезахищеної фанери сумішшю ДСА-2

\begin{tabular}{|c|c|c|c|}
\hline $\begin{array}{c}\text { № } \\
\text { зразка }\end{array}$ & $\begin{array}{c}\text { Характеристика } \\
\text { вогнезахищеного зразка фанери }\end{array}$ & $\begin{array}{c}\text { Втрата маси } \\
\text { зразка } \Delta \mathrm{m}, \\
\%\end{array}$ & $\begin{array}{c}\text { Максимальна } \\
\text { температура } \\
\text { газоподібних } \\
\text { продуктів } \\
\text { горіння } \Delta t,{ }^{\circ} \mathrm{C}\end{array}$ \\
\hline 1 & $\begin{array}{l}\text { Фанера. оброблена сумішшю } \\
\text { ДСЛ-2, товщиною } 5 \text { мм }\end{array}$ & 30,2 & 220,1 \\
\hline 2 & $\begin{array}{l}\text { Фанера, оброблена } \\
\text { ДСА-2 тамішшю } \\
\text { товщиною } 5 \text { мм }\end{array}$ & 36,1 & 221,2 \\
\hline 3 & $\begin{array}{l}\text { Фанера, оброблена сумішшю } \\
\text { ДСА-2, товщиною } 10 \text { мм }\end{array}$ & 22,1 & 215,4 \\
\hline 4 & $\begin{array}{l}\text { Фанера. оброблена сумішшю } \\
\text { ДСА-2, товщиною } 15 \text { мм }\end{array}$ & 18,3 & 183,3 \\
\hline 5 & $\begin{array}{l}\text { Фанера, оброблена сумішшю } \\
\text { ДСА-2 та сумішшю «Сілол», } \\
\text { товщиною } 15 \text { мм }\end{array}$ & 19,4 & 190,3 \\
\hline 6 & $\begin{array}{l}\text { Фанера. оброблена сумішшю } \\
\text { ДСА-2, товщиною } 20 \text { мм }\end{array}$ & 14,7 & 171,4 \\
\hline 7 & $\begin{array}{l}\text { Фанера. оброблена сумішшю } \\
\text { ДСА-2. товщиною } 30 \text { мм }\end{array}$ & 10,4 & 163,6 \\
\hline 8 & $\begin{array}{l}\text { Фанера, оброблена сумішшю } \\
\text { ДСА-2 та сумішшю «Сілол», } \\
\text { товщиною } 30 \text { мм }\end{array}$ & 11,6 & 174,6 \\
\hline
\end{tabular}




\section{Сільськогосподарські машини. Випуск 43}

Суть методу визначення індексу поширення полум'я [15] полягає в оцінюванні здатності матеріалу займатися, виділяти тепло та поширювати полум'я поверхнею під дією зовнішнього теплового потоку. На зразок, що встановлений під кутом $30^{\circ}$ до вертикалі, діє

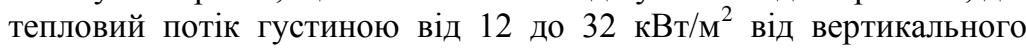
розміщеної радіаційної панелі. Верхня кромка зразка запалюється газовим пальником. Залежно від одержаного індексу поширення полум'я матеріали класифікуються як ті. що:

- не поширюють полум'я поверхнею - індекс поширення полум'я дорівнює 0;

- повільно поширюють полум'я поверхнею - індекс поширення полум'я від 0 до 20 включно;

- швидко поширюють полум'я поверхнею - індекс поширення полум'я більший 20.

Експериментальні дані щодо дослідження індексу поширення полум'я поверхнею зразків вогнезахищеної фанери наведено в таблиці 2.

Таблиця 2 - Експериментальні дані щодо дослідження індексу поширення полум'я поверхнею зразків вогнезахищеної фанери

\begin{tabular}{|c|l|c|}
\hline $\begin{array}{c}\text { № } \\
\text { зразка }\end{array}$ & $\begin{array}{l}\text { Характеристика вогнезахишеного зразка } \\
\text { фанери }\end{array}$ & $\begin{array}{c}\text { Iндекс поширення } \\
\text { полум’я }\end{array}$ \\
\hline 1 & Фанера необроблена, товщиною 5 мм & 47,4 \\
\hline 2 & $\begin{array}{l}\text { Фанера оброблена сумішшю ДСА-2, } \\
\text { товщиною 5 мм }\end{array}$ & 1,03 \\
\hline 3 & $\begin{array}{l}\text { Фанера, оброблена сумішшю ДСА-2 та } \\
\text { сумішшю «Сілол», товщиною 5 мм }\end{array}$ & 5,02 \\
\hline 4 & $\begin{array}{l}\text { Фанера оброблена сумішшю ДСА-2, } \\
\text { товщиною 15 мм }\end{array}$ \\
\hline 5 & $\begin{array}{l}\text { Фанера, оброблена сумішшю ДСА-2 та } \\
\text { сумішшю «Сілол», товщиною 15 мм }\end{array}$ & 0 \\
\hline
\end{tabular}

Згідно з визначеним ГОСТом визначено димоутворювальну здатність фанерної плити $(\delta=5 \mathrm{mм})$, обробленої ДСА-2 3 гідрофобізувальним покриттям «Сілол» [15].

Таким чином встановлено, що фанерна плита, яка оброблена ДСА-2 з гідрофобізувальним покриттям «Сілол» відноситься до важкогорючих матеріалів, які не (повільно) 
поширюють полум'я поверхнею, з помірною димоутворювальною здатністю за токсичністю продуктів горіння - помірно небезпечний, та відповідає вимогам ГОСТ 30219.

За розробленою Інститутом УкрНДІ «Ресурс» технологією виготовлення вогнезахищеної фанери на Київському ЗАТ «Фанплит» (провідному фанерному підприємстві України) створена дільниця, на якій впроваджена розроблена технологія. Виготовлено $160 \mathrm{~m}^{3}$ вогнезахищеної фанери різної товщини та форматів, яка сертифікована в Державному центрі сертифікації засобів протипожежного призначення.

Успішне виконання даної роботи було можливим за активного організаційного та фінансового сприяння Головного управління інноваційної, науково-технічної та промислової політики Київської міської державної адміністрації.

Висновки. За результатами досліджень встановлено, що фанерна плита, яка оброблена ДСА-2 з гідрофобізувальним покриттям «Сілол» відноситься до важкогорючих матеріалів, які не поширюють полум'я поверхнею, з помірною димоутворювальною здатністю. За токсичністю продуктів горіння вогнезахищена фанера помірно небезпечна та відповідає вимогам нормативно-технічної документації.

\section{Література}

1. Коньюктура мирового рынка. Журнал «WOOD business», №3, 1999 р. - с.34-35.

2. Підсумки роботи деревообробної, меблевої та целюлознопаперової промисловості України. Журнал «Світ меблів і деревини», №6, 2017 p.- с.7.

3. Межгосударственный стандарт ГОСТ 30213-93 Межгосударственный стандарт ГОСТ 30213-93 «Древесина огнезащищенная. Общие технические требования. Методы испытаний. Транспортирование и хранение». Межгосударственный совет по стандартизации, метрологии и сертификации. - Минск.1977.

4. Ермаков А.И., Завражнов А.М., Спиридонов Ю.Г. и др. Получение трудногорючих атмосферостойких древесных плит на основе волокнистой стружки / Деревообрабатывающая пром-сть. 2001. № 1. - с. 27-30.

5. Леонович А.А., Шелоумов А.В. Снижение пожарной опасности древесных материалов, изделий и строительных конструкцій. - СПб.:ГПУ, 2002. - 59 с. 
6. Влияние повышения температур на прочность древесины, обработанной огнезащитными составами. Novatov vaclov Viev evesene teplote no pevenost dreva impregnovanche JatcomI Snisujtcimhorlovoct. Drevoi. -1980.-35.-7.-194.-19.

7. Зарудная Г.И., Катаева О.А., Филиппов А.Е. зависимость прочности антипирированной древесины от плотности и поглощения. //Лесной журнал. - ИНВУЗ.-1980.-№1.c.53-55.

8. Леонович А.А., Шалун Г.Б. Огнезащита древесных плит и слоистых пластиков. - М.: Лесная пром-сть, 1974. - 128с.

9. Семенова В.М., Леонович А.А. К вопросу об огнезащите древесины и клееных конструкций. //Лесной журнал. - ИВУЗ. 1974.-6. c.94-99.

10. Рыков Р.И. К антисептированию клееной древесины. //В сб.: Особенности строительства в условиях Восточной Сибири. Иркутск. -1974. - с.70-78.

11. И.Забродлин А.Г., Янковская Н.А. Огнезащита стружечных плит. //В сб.: Механическая обработка древесины. ЦНИИТЭИлеспром. -1963. -с.25.

12. Хрулев Р.М., Зайвий В.А. Условия обеспечения долговечности клеефанерных строительных конструкций . //В сб.: Повышение эффективности конструкционного использования древесины в строительстве. Материалы Всесоюзного совещания. Ч.1.М.-1968.-С.56-58.

13. Обработка фанеры с целью повышения ее биостойкости. Treatment of panel products I non pressure treatment of vemeer and its effecton gluabelitu Kureel A.R., Saran Sftvn J. Timber Denelop. Asos. India. 1980. -26. № 3. - c.23-29.

14. Жартовський С.В., Грабовський О.В. Дослідження вогнезахисних властивостей важкогорючих фанерних плит. Науковий вісник. УкРНДІПБ. -2007. №1.(15) с.63- 68.

15. ГОСТ 12.1.044-1989 Пожаровзрывоопасность веществ и материалов. Номенклатура показателей и методы их определения. 